\title{
Yersinia aleksiciae sp. nov.
}

Correspondence

Lisa D. Sprague

natter13@gmx.de

\author{
Lisa D. Spraguet and Heinrich Neubauer
}

Bundeswehr Institute of Microbiology, Department of Bacteriology, Neuherbergstraße 11, D-80937 München, Germany

\begin{abstract}
Yersinia kristensenii consists of phenotypically heterogeneous strains. This is reflected by the existence of strains with various multilocus enzyme electrophoresis and 16S rRNA gene sequence types. Strains originally phenotyped as members of $Y$. kristensenii were studied using $16 \mathrm{~S}$ rRNA gene sequencing, DNA-DNA hybridization, determination of the DNA base composition and various phenotypic tests. The results were compared to those of Yersinia type strains. Based on levels of DNA-DNA relatedness, a specific 16S rRNA gene sequence type and the presence of lysine decarboxylase activity, a novel species, Yersinia aleksiciae sp. nov., is proposed. The type

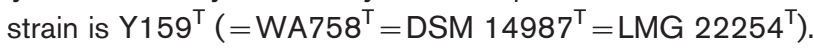

Yersinia kristensenii was described to accommodate strains that are trehalose-positive, ornithine decarboxylase-positive and rhamnose-negative. These are mostly adapted to the soil ecosystem. The $\mathrm{G}+\mathrm{C}$ content of the DNA has been determined to be $48 \cdot 5 \pm 0 \cdot 5 \mathrm{~mol} \%$ and two hybridization clusters have been found (Bercovier et al., 1980). Of 115 Y. kristensenii strains investigated, $7 \%$ belonged to serogroup O:16 (Bercovier et al., 1980). Aleksic \& Bockemühl (1984) discovered an O:16 antigen specific for Y. kristensenii. In successive studies it was noted that $Y$. kristensenii strains with various multilocus enzyme electrophoresis (MLEE) clusters exist (Goullet \& Picard, 1988; Caugant et al., 1989; Dolina \& Peduzzi, 1993). Neubauer et al. (2000a) were able to demonstrate the existence of at least two distinct 16S rRNA gene sequence types for Yersinia enterocolitica and Y. kristensenii. The possibility that $Y$. kristensenii might therefore comprise at least two distinct species was suggested (Sulakvelidze, 2000; Neubauer et al., 2000a).

The aim of this present study was to investigate whether isolates originally phenotyped as members of $Y$. kristensenii

Published online ahead of print on 29 October 2004 as DOI 10.1099/ ijs.0.63220-0.

†Present address: Klinik und Poliklinik für Strahlentherapie und Radiologische Onkologie der TU-München, Klinikum rechts der Isar, Ismaningerstraße 22, 81675 München, Germany.

Abbreviations: LDC, lysine decarboxylase; MLEE, multilocus enzyme electrophoresis.

The GenBank/EMBL/DDBJ accession numbers for the 16S rRNA gene sequences of strains Y221, Y156, Y159 ${ }^{\top}, Y 160, Y 390, Y 389$ and $Y 388$ are AJ627594, AJ627595 and AJ627597-AJ627601, respectively.

Phenotypic characteristics and DNA-DNA hybridization results for various Yersinia isolates are available as supplementary tables in IJSEM Online. displaying different $16 \mathrm{~S}$ rRNA gene sequence types may be representative of a novel species.

Five Yersinia isolates originally phenotyped as Y. kristensenii serotype O : 16 were supplied by Dr G. Wauters (Université Catholique de Louvain, Brussels, Belgium; strain names prefixed by WA). Strains $\mathrm{Y} 159^{\mathrm{T}}$ (=WA758 $8^{\mathrm{T}}$; GenBank/ EMBL accession no. AJ627597) and Y390 (=WA948; AJ627599) were isolated from human faeces in Finland (by M. Skurnik in 1981). Strain Y221 (=WA120; GenBank/ EMBL accession no. AJ627594) was isolated from pork products in Toronto, Canada (by D. A. Schiemann in 1979). Strain Y389 (=WA31A/89; GenBank/EMBL accession no. AJ627600) was isolated from rats and moles in Japan (by H. Fukushima in 1989). Strain Y388 (=WA8/90; GenBank/ EMBL accession no. AJ627601) was isolated from dairy products in Australia (by D. Hughes in 1990). Strains Y156 $(\mathrm{O}: 12,25)$ (GenBank/EMBL accession no. AJ627595) and Y216 (O : nt) phenotyped as Y. kristensenii were of unknown origin. Additionally, a panel of Yersinia strains phenotyped as Y. kristensenii was investigated. These strains were isolated from reindeer faeces in Finland during the years 2000-2002: Y479 (Lappi, Finland), Y489 and Y490 (Tromsö, Finland) and Y473 (Näkkälä, Finland); and strain Y475 was isolated from soil (by N. Kemper, Kiel, Germany). The serogroup of these strains is unknown. Two Y. kristensenii strains (Y157 $\mathrm{O}: 11,23$ and Y160 O:28; GenBank/EMBL accession no. AJ627598) were of the $16 \mathrm{~S}$ rRNA gene sequence type A [5' AAGGCARTCGTGTTAATAGCACGRTTGATT-3'; representing positions $451-480$ of the type strain ATCC $33638^{\mathrm{T}}$ $\left(=\mathrm{Y} 110^{\mathrm{T}}\right)($ Neubauer et al., 2000a)]. The following type strains of Yersinia species or subspecies were also investigated: Yersinia enterocolitica subsp. palearctica DSM $13030^{\mathrm{T}}$, Y. enterocolitica subsp. enterocolitica ATCC $9610^{\mathrm{T}}$, Yersinia ruckeri ATCC $29473^{\mathrm{T}}$, Yersinia pseudotuberculosis ATCC $29833^{\mathrm{T}}$, Yersinia frederiksenii ATCC $33641^{\mathrm{T}}$, Yersinia bercovieri ATCC $43970^{\mathrm{T}}$, Yersinia rohdei ATCC $43380^{\mathrm{T}}$, 
Yersinia mollaretii ATCC $43969^{\mathrm{T}}$, Yersinia aldovae ATCC $35236^{\mathrm{T}}\left(=\mathrm{Y}_{112^{\mathrm{T}}}\right)$ and Yersinia intermedia ATCC $29909^{\mathrm{T}}$ $\left(=\mathrm{Y} 118^{\mathrm{T}}\right)$. The last of these is lysine decarboxylase (LDC)negative. For comparative studies, Y. aldovae strain Y186 and Y. intermedia strains Y20 and Y154 (both the latter strains are LDC-positive) were used. Strains were maintained on standard nutrient agar I (Oxoid) at $4{ }^{\circ} \mathrm{C}$. Subcultivation was on blood agar overnight at $28^{\circ} \mathrm{C}$. Broth culture was carried out overnight in LB medium (Difco) at $28^{\circ} \mathrm{C}$ and 150 r.p.m. in controlled environment shakers (New Brunswick). Cells were harvested by centrifugation $(1200 \mathrm{~g})$ and stored in $70 \%$ 2-propanol at $4{ }^{\circ} \mathrm{C}$ until used for DNA-DNA hybridization experiments.

Identification of Yersinia isolates was performed as described by Neubauer et al. (2000b) except that incubation was for $72 \mathrm{~h}$. An LDC cut-off value of an absorbance of $0 \cdot 1$ was used. API 20E (bioMérieux) tests were performed as described by the manufacturer. PCR assays for genes encoding pathogenicity factors (yadA, $\mathrm{V}$-antigen) were performed as described by Neubauer et al. (2000d).

Spectroscopic DNA-DNA hybridization experiments were performed at $62{ }^{\circ} \mathrm{C}$ with $10 \%$ DMSO. DNA was isolated by chromatography on hydroxyapatite (Cashion et al., 1977). DNA-DNA hybridization was performed by spectroscopy in $10 \%$ DMSO at $62^{\circ} \mathrm{C}$ using a Gilford System model 2600 spectrometer equipped with a Gilford model 2527-R thermoprogrammer and plotter (De Ley et al., 1970; Huß et al., 1983; Escara \& Hutton, 1980). Renaturation rates were computed with the TRANSFER.BAS program (Jahnke, 1992). A deviation of $5 \%$ in DNA-DNA relatedness values can be tolerated when comparing individual experiments (see Supplementary Tables B and C in IJSEM Online). The DNA $\mathrm{G}+\mathrm{C}$ content was determined in three independent measurements. Cells were disrupted using a French pressure cell and the DNA was purified as described by Mesbah et al. (1989) and Tamaoka \& Komagata (1984). An HPLC system (Shimadzu Corp.) and NUCLEOSIL 100-5C18 in combination with a pre-column NUCLEOSIL 100-5C18 (both from Macherey and Nagel) were used. Both analyses were carried out at the Deutsche Sammlung von Mikroorganismen und Zellkulturen, Braunschweig, Germany.

Determination of the 16S rRNA gene sequence type of Yersinia isolates was performed as described by Neubauer et al. (2000a) using the sequencing primer pair SP1 (5'-GAATATTGCACAATGGGCGCA-3') and SP3 (5'AACAAACCGCCTGCGTGCGC-3'). The amplicons produced from two independent cultures were sequenced in both directions. Partial sequencing of the 16S rRNA gene of Yersinia strains was performed using primers 16-1 (5'-AGAGTTTGATCCTGGCTCA-3'), 16-2 (5'-CACCGG CTAACTCCGTGCCA-3' $\left.{ }^{\prime}\right)$, 16-3 (5'-GAGACAGGTGCTG CATGGCT- $\left.3^{\prime}\right), \quad$ PT2 (5'-GGCAACAAAGGATAA- $\left.3^{\prime}\right)$ (Neubauer et al., 2000e), 16-4 (5'-TACCTTGTTACGA CTTCTC- $\left.3^{\prime}\right)$ and 16-5 (5'-TTCCGATTAACGCTTGCA CC- $\left.3^{\prime}\right)$. PCR products were sequenced in both directions.
Interpretation of the results was aided by use of Lasergene software (DNASTAR) based on the CLUSTAL method.

Cells of strains isolated from reindeer, including $\mathrm{Y} 159^{\mathrm{T}}$, Y216, Y221, Y388, Y389 and Y390, were small, Gramnegative, motile, coccoid rods. All isolates were catalase- and urease-positive and oxidase-negative. They were trehalosepositive, ornithine decarboxylase-positive and rhamnosenegative. The principal API $20 \mathrm{E}$ profile obtained was 1114703 (data not shown). Based on these findings, their classification within Y. kristensenii was justified (Bercovier et al., 1980). However, these strains differed from other Y. kristensenii strains identified by a semi-automated system for identification of species within the genus Yersinia (Neubauer et al., 2000b) in that all were LDC-positive. This feature is usually not used for the differentiation of Yersinia species (Supplementary Table A). In a recent investigation we found that LDC activity was only present in strains $\mathrm{Y}_{159^{\mathrm{T}}}, \mathrm{Y} 216$ and Y221 of Y. kristensenii and in $42 \%$ of the isolates of Y. intermedia, including Y154 and Y20, but not in the type strain (Neubauer et al., 2000b). These LDC-positive $Y$. intermedia strains, in contrast to the LDC-positive strains $\mathrm{Y}_{159^{\mathrm{T}}}, \mathrm{Y} 216, \mathrm{Y} 221, \mathrm{Y} 388, \mathrm{Y} 389, \mathrm{Y} 390$ and the LDC-positive reindeer strains, were aesculin-, salicin-, citrate- and sucrose-positive. A highly fermentative phenotype clearly distinguishes both groups of isolates. In accordance with these findings, LDC-positive $Y$. intermedia strains showed only $37 \cdot 5-48 \cdot 7 \%$ DNA-DNA relatedness to LDC-positive Y. kristensenii isolates (Supplementary Table B). Furthermore, these strains showed only a low level of DNA-DNA relatedness to the Y. kristensenii type strain. Pathogenicity in Yersinia is linked to the presence of the $64 \mathrm{kDa}$ Yersinia virulence plasmid encoding a type III secretion system and various effector proteins (Cornelis, 2002). Neither the plasmid-borne gene of the Yersinia adhesin nor the $\mathrm{V}$-antigen, which plays a role as a regulator in the secretion of effector proteins, generated PCR products in the Y. kristensenii-like LDC-positive strains investigated here. Thus, the plasmid-borne markers for Yersinia pathogenicity are missing. Nonetheless, these strains should be grouped into risk class 2 until apathogenicity has been confirmed.

A further apparent difference was that strains $\mathrm{Y} 159^{\mathrm{T}}$, Y216, Y221, Y388, Y389, Y390 and all reindeer strains belonged to $16 \mathrm{~S}$ rRNA gene sequence type $\mathrm{B}$, representing positions 451-480 of the Escherichia coli 16S rRNA gene sequence (IUB nomenclature, 5'-AAGGGTTCAGTGTTAATAGCACTGAGCATT-3') (Neubauer et al., 2000a). For the description of the 16S rRNA gene sequence type, only $30 \mathrm{nt}$ have been taken into consideration (Neubauer et al., 2000a, c). In $Y$. enterocolitica, specific $16 \mathrm{~S}$ rRNA gene sequence types have been used to define the subspecies $Y$. enterocolitica subsp. enterocolitica and $Y$. enterocolitica subsp. palearctica. The American phenotype biovar 1B strains are represented by a unique 16S rRNA gene sequence type which is clearly distinct from that of the European phenotype of biovars 1A, 2, 3, 4 and 5 (Ibrahim et al., 1993; Neubauer et al., 2000c). It therefore seemed clear that the 
$16 \mathrm{~S}$ rRNA gene sequence type could be used for the definition of a novel species. Three strains of $16 \mathrm{~S}$ rRNA gene sequence type $\mathrm{A}$ ( $Y$. kristensenii: $\left.\mathrm{Y} 110^{\mathrm{T}}, \mathrm{Y} 157, \mathrm{Y} 160\right)$ and two strains of 16S rRNA gene sequence type B $\left(\mathrm{Y} 159^{\mathrm{T}}\right.$, Y221) were subjected to DNA-DNA hybridization analysis (Supplementary Table C). Y. kristensenii strains Y157 and Y160 clustered into the group represented by the type strain of Y. kristensenii $\left(\mathrm{Y} 110^{\mathrm{T}}\right)$ with an intragroup relatedness of $86 \cdot 6-94 \cdot 7 \%$. This result demonstrated that both isolates had been correctly phenotyped. These strains are members of the genomic species Y. kristensenii (Johnson, 1984; Wayne et al., 1987; Stackebrandt \& Liesack, 1993). A further group was formed by isolates $\mathrm{Y} 159^{\mathrm{T}}$ and $\mathrm{Y} 221$, with an intragroup similarity of $89 \cdot 0 \%$ (Supplementary Table C). Strains Y388 and Y216 have levels of relatedness of $84 \cdot 3$ and $83.9 \%$ to Y159 ${ }^{\mathrm{T}}$, respectively (Supplementary Table B). Their intergroup relatedness ranged from 28.6 to $47 \%$, demonstrating that neither strain belongs to Y. kristensenii (Supplementary Table C). Strains $\mathrm{Y}_{159^{\mathrm{T}}}$ and $\mathrm{Y} 221$ had levels of relatedness of $22 \cdot 5-61 \cdot 7 \%$ to those Yersinia type strains that are most closely related to Y. mollaretii (Supplementary Table D). A high similarity value between the $16 \mathrm{~S}$ rRNA gene sequence type B was demonstrated for the 16S rRNA gene sequence type found in Y. aldovae (Neubauer et al., 2000a). However, DNA-DNA hybridization studies of strains $\mathrm{Y}^{159^{\mathrm{T}}}$ and Y221 and two $Y$. aldovae strains $\left(\mathrm{Y} 112^{\mathrm{T}}, \mathrm{Y} 186\right)$ revealed an intergroup relatedness of only $22 \cdot 5-46 \cdot 9 \%$ (Supplementary Table C). Consequently, strains $\mathrm{Y}_{159^{\mathrm{T}}}$ and $\mathrm{Y} 221$ comprise a genomic species (Johnson, 1984; Wayne et al., 1987; Stackebrandt \& Liesack, 1993; Stackebrandt et al., 2002) characterized by their LDC-positive phenotype and a specific $16 \mathrm{~S}$ rRNA gene sequence type. Hereafter, we refer to these strains as strains of Yersinia aleksiciae sp. nov. We can conclude that the 16S rRNA gene sequence type $\mathrm{A}$ is a species-specific marker for Y. kristensenii and 16S rRNA gene sequence type B for $Y$. aleksiciae.

A $16 \mathrm{~S}$ rRNA gene sequence similarity of $97 \%$ corresponds to a $70 \%$ level of DNA-DNA relatedness. This value is considered to be the standard for species definition (Stackebrandt \& Liesack, 1993; Stackebrandt \& Goebel, 1994; Stackebrandt et al., 2002). In comparing the 16 S rRNA gene sequences of the type strains of the species of the genus Yersinia, levels of DNA-DNA relatedness never fall below $97 \cdot 4 \%$. To determine whether LDC-positive Y. aleksiciae strains of the $16 \mathrm{~S}$ rRNA gene sequence type might fulfil this criterion, nearly complete $16 \mathrm{~S}$ rRNA gene sequences (1419 nt) of strains $\mathrm{Y}_{110^{\mathrm{T}}}, \mathrm{Y} 156, \mathrm{Y} 157, \mathrm{Y} 160, \mathrm{Y} 159^{\mathrm{T}}$, Y216, Y388, Y389, Y390 and Y221 were determined. LDCpositive strains showed a 16S rRNA gene sequence similarity of $99 \cdot 9 \%$. Similarity to $Y$. kristensenii strains $\mathrm{Y}_{110^{\mathrm{T}}}$, Y156, Y157 and Y160 and to the type strains of other Yersinia species, however, was $98 \cdot 3-98 \cdot 8 \%$, which would not allow the definition of a novel species (data not shown). However, in cases where 16S rRNA gene sequence similarity is not discriminatory, DNA-DNA hybridization can be used to delineate a novel species (Stackebrandt et al., 2002).
The DNA G $+\mathrm{C}$ content has thus to be determined (Stackebrandt et al., 2002). The mean G $+\mathrm{C}$ content of $Y$. kristensenii type strain $\mathrm{Y} 110^{\mathrm{T}}$ was $50 \cdot 0 \mathrm{~mol} \%$ (two readings). This was $1.5 \mathrm{~mol} \%$ above the previously published value (Bercovier et al., 1980). Strains Y156, Y157 and Y160 of this species had values of 50.1, 49.2 and $50.5 \mathrm{~mol} \%$, respectively. The $\mathrm{G}+\mathrm{C}$ content of $Y$. aleksiciae $\mathrm{Y} 159^{\mathrm{T}}$ was 51.1 and $45.2 \mathrm{~mol} \%$ (two readings), giving a mean value of $48.1 \mathrm{~mol} \%$. Other strains of $Y$. aleksiciae, Y216, Y221 and Y388, had G $+C$ values of $45 \cdot 7,50 \cdot 9$ and $46.1 \mathrm{~mol} \%$, respectively. These estimates are within the accepted limits for the genus Yersinia of $46-50 \mathrm{~mol} \%$ (Bercovier \& Mollaret, 1984). The differences of up to $5 \mathrm{~mol} \%$ observed within individual series of measurements were the result of the technique and equipment used.

The taxonomic position of strain Y156 remains unclear because this isolate is a member of $16 \mathrm{~S}$ rRNA gene sequence type B but is LDC-negative, thus displaying the classical metabolic activity of Y. kristensenii. Strain Y156 was clearly separated from the 16S rRNA gene sequence similarity cluster formed by strains $\mathrm{Y} 110^{\mathrm{T}}$, Y157 and Y160 within the species $Y$. kristensenii, and with a DNA-DNA relatedness level of $70 \cdot 8 \%$ to the type strain was at the limit for inclusion in this species. However, strain Y156 had a high 16S rRNA gene sequence similarity $(99 \cdot 2 \%)$ to the type strain of Y. kristensenii. Its $16 \mathrm{~S}$ rRNA gene sequence also showed higher similarity to that of the type strains of $Y$. aldovae and Y. mollaretii. Genomic relatedness of strains identified as $Y$. kristensenii to $Y$. mollaretii has been previously demonstrated in MLEE studies (Goullet \& Picard, 1988; Caugant et al., 1989; Dolina \& Peduzzi, 1993). Data from published studies cannot be used to clarify whether these strains might be members of the genomic species Y. aleksiciae sp. nov. The role of the $\mathrm{O}$-antigen $\mathrm{O}: 16$ as a phenetic marker could not be elucidated here. However, there is strong evidence that it is specific to Y. aleksiciae.

The ad hoc committee for the re-evaluation of the species definition in bacteriology of the ICSP encouraged 'the use of innovative methods for prokaryotic systematics, e.g. $16 \mathrm{~S}$ rDNA sequencing' (Stackebrandt et al., 2002). Using $16 \mathrm{~S}$ rRNA gene sequence type analysis in combination with DNA-DNA hybridization on a collection of Yersinia strains, we were able to define the novel species $Y$. aleksiciae within the genus Yersinia. Nonetheless, except for the LDC reaction, phenotypic tests are unable to differentiate the type strains of $Y$. kristensenii and $Y$. aleksiciae. However, our DNA-DNA relatedness studies clearly support the differentiation of the two species into Y. kristensenii sensu stricto and Y. aleksiciae. Single phenetic and genomic markers have previously been used in systematics to characterize a species (Yassin et al., 2002).

The importance of this novel species for ecologists, evolution geneticists and clinical microbiologists must be emphasized. Members of the novel species seem to be well adapted to warm-blooded animals, including humans. Strains have been isolated from the faeces of humans, 
rats, moles, reindeer and pigs, and from dairy products. Therefore, it can be concluded that $Y$. aleksiciae is not host specific. Y. aleksiciae is widely distributed and has been isolated in Europe, America, Australia and Asia. It remains to be proven whether it is a member of the normal flora in the digestive tract of various mammals. Members of $Y$. aleksiciae have been isolated regularly within the past few years from reindeer in Finland and Norway using $16 \mathrm{~S}$ rRNA gene sequence type analysis and LDC reactivity as markers (data not shown).

\section{Description of Yersinia aleksiciae sp. nov.}

Yersinia aleksiciae (al.ek'sic.i.ae. N.L. gen. n. aleksiciae in honour of Professor Stojanca Aleksic, Hamburg, Germany, to whom we owe much of our knowledge on the epidemiology and microbiology of Yersinia).

Gram-negative, motile, coccoid rods. Cells are catalase- and urease-positive, oxidase-negative and reduce nitrate. Trehalose-, catalase- and urease-positive, oxidase-negative, ornithine decarboxylase-positive, rhamnose-negative but LDC-positive. Aesculin-, salicin-, citrate- and sucrosenegative. Strains belong to the $16 \mathrm{~S}$ rRNA gene sequence type 5'-AAGGGTTCAGTGTTAATAGCACTGAGCATT-3', representing positions $451-480$ of the E. coli 16S rRNA gene sequence (IUB nomenclature). The DNA G $+\mathrm{C}$ content of the type strain is $48 \cdot 1 \mathrm{~mol} \%$.

The type strain is strain $\mathrm{Y}^{159^{\mathrm{T}}}\left(=\mathrm{WA} 758^{\mathrm{T}}=\mathrm{DSM}\right.$ $14987^{\mathrm{T}}=$ LMG $22254^{\mathrm{T}}$ ), belonging to serogroup O : 16 .

\section{Acknowledgements}

The excellent technical assistance of C. Lodri and R. Schneider is gratefully acknowledged. We thank G. Wauters, Brussels, Belgium, for assistance and valuable discussion, and Dr H.-J. Busse, Vienna, Austria, for discussion.

\section{References}

Aleksic, S. \& Bockemühl, J. (1984). Proposed revision of the Wauters et al. antigenic scheme for serotyping of Yersinia enterocolitica. J Clin Microbiol 20, 99-102.

Bercovier, H. \& Mollaret, H. H. (1984). Genus XIV. Yersinia Van Loghem 1944, 15 ${ }^{\mathrm{AL}}$. In Bergey's Manual of Systematic Bacteriology, vol. 1, pp. 498-506. Edited by N. R. Krieg \& J. G. Holt. Baltimore: Williams \& Wilkins.

Bercovier, H., Ursing, J., Brenner, D. J., Steigerwaldt, A. G., Fanning, G. R., Carter, G. P. \& Mollaret, H. H. (1980). Yersinia kristensenii: a new species of Enterobacteriaceae composed of sucrose negative strains (formerly called atypical Yersinia enterocolitica or Yersinia enterocolitica-like). Curr Microbiol 4, 219-224.

Cashion, P., Holder-Franklin, M. A., McCully, J. \& Franklin, M. (1977). A rapid method for the base ratio determination of bacterial DNA. Anal Biochem 81, 461-466.

Caugant, D. A., Aleksic, S., Mollaret, H. H., Selander, R. K. \& Kapperud, G. (1989). Clonal diversity and relationships among strains of Yersinia enterocolitica. J Clin Microbiol 27, 2678-2683.
Cornelis, G. R. (2002). The Yersinia Ysc-Yop virulence apparatus. Int J Med Microbiol 291, 455-462.

De Ley, J., Cattoir, H. \& Reynaerts, A. (1970). The quantitative measurement of DNA hybridization from renaturation rates. Eur J Biochem 12, 133-142.

Dolina, M. \& Peduzzi, R. (1993). Population genetics of human, animal, and environmental Yersinia strains. Appl Environ Microbiol 59, 442-450.

Escara, J. F. \& Hutton, J. R. (1980). Thermal stability and renaturation of DNA in dimethyl sulfoxide solutions: acceleration of the renaturation rate. Biopolymers 19, 1315-1327.

Goullet, P. \& Picard, B. (1988). Characterisation of Yersinia enterocolitica, Y. intermedia, Y. aldovae, Y. frederiksenii, Y. kristensenii and $Y$. pseudotuberculosis by electrophoretic polymorphism of acid phosphatase, esterases, and glutamate and malate dehydrogenases. J Gen Microbiol 134, 317-325.

Huß, V. A. R., Festl, H. \& Schleifer, K. H. (1983). Studies on the spectrometric determination of DNA hybridization from renaturation rates. Syst Appl Microbiol 4, 184-192.

Ibrahim, A., Goebel, B. M., Liesack, W., Griffiths, M. \& Stackebrandt, E. (1993). The phylogeny of the genus Yersinia based on 16S rDNA sequences. FEMS Microbiol Lett 114, 173-177.

Jahnke, K.-D. (1992). Basic computer program for the evaluation of spectroscopic DNA renaturation data from GILFORD System 2006 spectrometer on a PC/XT/AT type personal computer. J Microbiol Methods 15, 61-73.

Johnson, J. L. (1984). Nucleic acids in bacterial classification. In Bergey's Manual of Systematic Bacteriology, vol. 1, pp. 8-11. Edited by N. R. Krieg \& J. G. Holt. Baltimore: Williams \& Wilkins.

Mesbah, M., Premachandran, U. \& Whitman, W. B. (1989). Precise measurement of the $\mathrm{G}+\mathrm{C}$ content of deoxyribonucleic acid by high-performance liquid chromatography. Int J Syst Bacteriol 39, 159-167.

Neubauer, H., Hensel, A., Aleksic, S. \& Meyer, H. (2000a). Identification of Yersinia enterocolitica within the genus Yersinia. Syst Appl Microbiol 23, 58-62.

Neubauer, H., Molitor, M., Rahalison, L., Aleksic, S., Backes, H., Chanteau, S. \& Meyer, H. (2000b). A miniaturised semiautomated system for identification of Yersinia species within the genus Yersinia. Clin Lab 46, 561-567.

Neubauer, H., Aleksic, S., Hensel, A., Finke, E.-J. \& Meyer, H. (2000c). Yersinia enterocolitica 16S rRNA gene types belong to the same genospecies but form three different homology clusters. Int J Med Microbiol 290, 61-64.

Neubauer, H., Sprague, L. D., Hensel, A., Aleksic, S. \& Meyer, H. (2000d). Specific detection of plasmid bearing Yersinia isolates by PCR. Clin Lab 46, 583-587.

Neubauer, H., Meyer, H., Prior, J., Aleksic, S., Hensel, A. \& Splettstösser, W. (2000e). A combination of different polymerase chain reaction (PCR) assays for the presumptive identification of Yersinia pestis. J Vet Med B Infect Dis Vet Public Health 47, 573-580.

Stackebrandt, E. \& Goebel, B. M. (1994). Taxonomic note: a place for DNA-DNA reassociation and 16S rRNA sequence analysis in the present species definition in bacteriology. Int J Syst Bacteriol 44, 846-849.

Stackebrandt, E. \& Liesack, W. (1993). Nucleic acids and classification. In Handbook of New Bacterial Systematics, pp. 151-194. Edited by A. G. O'Donnell. London: Academic Press.

Stackebrandt, E., Frederiksen, W., Garrity, G. M. \& 10 other authors (2002). Report of the ad hoc committee for the re-evaluation of the species definition in bacteriology. Int J Syst Evol Microbiol 52, 1043-1047. 
Sulakvelidze, A. (2000). Yersiniae other than Y. enterocolitica, $Y$. pseudotuberculosis, and Y. pestis: the ignored species. Microbes Infect 2, 497-513.

Tamaoka, J. \& Komagata, K. (1984). Determination of DNA base composition by reverse-phased high performance liquid chromatography. FEMS Microbiol Lett 25, 125-128.
Wayne, L. G., Brenner, D. J., Colwell, R. R. \& 9 other authors (1987). Report of the ad hoc committee on reconciliation of approaches to bacterial systematics. Int J Syst Bacteriol 37, 463-464.

Yassin, A. F., Steiner, U. \& Ludwig, W. (2002). Corynebacterium appendicis sp. nov. Int J Syst Evol Microbiol 52, 1165-1169. 